\title{
Efektivitas Pijat Bayi Terhadap Perubahan Berat Badan Bayi 3-6 Bulan di Posyandu Deho di Wilayah Kerja Puskesmas Hamadi Jayapura tahun 2019
}

\section{Triana Indrayani, Marlyina, Jenny Anna Siauta}

Universitas Nasional, Jakarta

Corresponding author: Triana Indrayani (triana.indrayani@yahoo.com)

Received: December, 16 2019; Accepted: January, 19 2020; Published: March, 162020

\begin{abstract}
ABSTRAK
Berdasarkan Dinas Kesehatan Provinsi Papua tahun 2017 masalah gizi buruk pd balita 0-23 bulan sebesar 3,1\%. Stimulasi dalam masa bayi sangat membantu dalam mencapai pertumbuhan yang optimal.

Metode penelitian yang digunakan dalam penelitian ini adalah dengan Quasi-Experimental Design, pre dan post test with Control Group Design. Teknik pengambilan sampel menggunakan Purposive Random Sampling.Sampel pada penelitian ini adalah bayi yang berusia 3-6 bulan sebanyak 30 Bayi. 15 bayi akan dijadikan kelompok Eksperimen dan 15 bayi akan dijadikan kelompok Kontrol. Data dianalisis menggunakan uji Paired sample t-test. Hasil penelitian menunjukan bahwa ada pengaruh pijat bayi terhadap perubahan berat badan bayi 3-6 bulan ( $\mathrm{P}$ value $=0,000)$ yang berarti $\mathrm{P}$ value $<$ a .

Adanya pengaruh pijat bayi terhadap perubahan berat badan bayi 3-6 bulan di Posyandu Deho tahun 2019. Pijat bayi dapat dijadikan intervensi dalam mengoptimalkan pertumbuhan anak.
\end{abstract}

Kata Kunci: Efektivitas, Pijat Bayi, Perubahan Berat Badan

This is an open-acces article distributed under the terms of the Creative Commons Attribution-ShareAlike 4.0 International License.

\section{PENDAHULUAN}

Masa bayi adalah masa keemasan sekaligus masa kritis perkembangan seseorang.Masa kritis bayi dimana bayi sangat peka terhadap lingkungan.Masa keemasan adalah masa bayi yang berlangsung sangat singkat dan tidak dapat diulang kembali (Sulung \& Gayatri, 2014).

Pertumbuhan dan perkembangan anak merupakan hal yang berhubungan dengan segala upaya menjaga dan mengoptimalnya tumbuh kembang anak baik fisik, mental, sosial serta kelainan tumbuh kembang yang kemungkinan penanganan yang tidak efektif, serta mencari penyebab dan mencegah keadaan tersebut.Manifestasi pertumbuhan salah satunya adalah berat badan yang juga salah satunya dapat dipengaruhi oleh makanan atau nutrisi (Hady, 2016). 
Beberapa faktor yang mempengaruhi proses pertumbuhan dan perkembangan bayi diantaranya adalah keturunan dan lingkungan. Faktor keturunan (genetic) ini berhubungan dengan gen yang diberikan dari seorang ayah dan ibu kepada anaknya. Faktor lingkungan (environment) terdiri dari lingkungan biologis, fisik, sosial dan psikologis. Pertumbuhan dan perkembangan merupakan hasil interaksi dari dua faktor tersebut yang mempengaruhi kualitas proses pertumbuhan dan perkembangan seorang anak (Chamidah, 2013).

Menurut World Health Organization (WHO) gangguan pertumbuhan dan gizi mengakibatkan $42 \%$ kematian bayi dan balita. Hasil sensus WHO menunjukan bahwa 49\% dari 10,4 juta kematian bayi dan balita di negara berkembang berkaitan dengan gangguan berat badan dan gizi buruk. Tercatat sekitar 50\% bayi dan balita di Asia, 30\% di Afrika, 20\% di Amerika Latin menderita gangguan berat badan dan gizi buruk (WHO, 2013). Sementara itu kasus bayi dan balita dengan gangguan berat badan di Indonesia juga masih sangat mencapai 19,6\% (Riskesdas, 2018).

Salah satu hal yang bisa dilakukan dalam menangani masalah gizi buruk adalah mengatur pola makan atau pemberian gizi.Salah satu penyebab permasalahan berat badan adalah nafsu makan anak yang turun.Hal ini bisa diatasi dengan pemberian suplemen atau vitamin pada anak ataupun stimulasi dan rangsangan.Salah satu rangsangan dan stimulasi yang dianjurkan adalah pijat bayi (Roesli, 2013). Pijat bayi dapat digolongkan sebagai aplikasi stimulasi sentuhan, karena dalam pijat bayi terapat unsur sentuhan berupa kasih sayang, perhatian, suara atau bicara, pandangan mata, gerakan, dan pijatan. Stimulasi ini akan merangsang perkembangan struktur maupun fungsi sel - sel otak (Soedjatmiko, 2013).

Menurut American Association of Message Therapy (AMTA) di definisikan sebagai manipulasi pada jaringan lunak yang dilakukan secara manual dengan menggunakan tangan atau tubuh untuk memegang, menggerakan, dan memberikan penekanan pada tubuh (AMTA, 2013). Berdasarkan penelitian yang dilakukan oleh Tri Sunarsih (2010), pijat bayi sangat berpengaruh terhadap kenaikan berat badan bayi. Dibuktikan pada hasil kelompok eksperimen mengalami peningkatan berat badan sebesar 17,32\% dan kelompok kontrol meningkat sebesar $13,48 \%$. Studi pendahuluan yang dilakukan peneliti di Posyandu Deho, pada bulan Oktober sampai November ada 60\% bayi usia 3-6 bulan yang pada saat kunjungan bayi dan dilakukan penimbangan berat badannya tidak naik. Peneliti juga melakukan wawancara kepada 2 ibu yang pernah melakukan pijat bayi di tempat pijat tradisional.Ibu mengatakan bahwa bayinya lebih nyenyak tidurnya, frekuensi menyusu lebih sering dan bertambah berat badannya.

Berdasarkan data di atas, maka peneliti tertarik untuk melakukan penelitian tentang efektivitas pijat bayi terhadap perubahan berat badan bayi 3-6 bulan di Posyandu Deho di wilayah kerja Puskesmas Hamadi Jayapura tahun 2019.

\section{METODE}

Metode penelitian yang digunakan dalam penelitian ini adalah dengan QuasiExperimental Design, pre dan post test with Control Group Design, Quasi eksperimen adalah penelitian yang digunakan untuk mencari pengaruh perlakuan tertentu terhadap yang lain dalam kondisi yang terkendali. Penelitian ini dilakukan di Posyandu Deho di wilayah kerja Puskesmas Hamadi Jayapura pada bulan Desember 2018 - Maret 2019.

Sampel yang digunakan pada penelitian ini bayi yang berusia 3-6 bulan sebanyak 30 Bayi. 15 bayi akan dijadikan kelompok Eksperimen dan 15 bayi akan dijadikan kelompok Kontrol. 
HASIL

\section{Tabel 1.Hasil Bivariat \\ Efektivitas Pijat Bayi Terhadap Perubahan Berat Badan Bayi 3-6 Bulan Pada Kelompok Eskperimen dan Kontrol di Posyandu Deho}

\begin{tabular}{lccc}
\hline & Mean & SD & P. Value \\
\hline $\begin{array}{l}\text { BB dengan } \\
\text { pemijatan }\end{array}$ & 376 & 76.045 & \\
$\begin{array}{l}\text { BB tanpa } \\
\text { pemijatan }\end{array}$ & 120 & 120.712 & 0,000 \\
\hline
\end{tabular}

Berdasarkan tabel 1 Hasil uji t diperoleh nilai $\mathrm{P}$ value $=0,000$ yang berarti $\mathrm{P}$ value $<a$ maka dapat disimpulkan dalam penelitian ini pijat bayi efektif dalam peningkatan perubahan berat badan bayi usia 3-6 bulan di Posyandu Deho di wilayah kerja Puskesmas Hamadi Jayapura tahun 2019.

\section{PEMBAHASAN}

\section{Analisis Bivariat}

\section{Pengaruh Efektivitas Pijat Bayi Terhadap Perubahan Berat Badan Bayi 3-6 Bulan Pada Kelompok Eskperimen dan Kontrol di Posyandu Deho}

Berdasarkan Tabel 1 hasil analisis tabel berat badan bayi antara kelompok eksperimen dengan kelompok kontrol, perubahan berat badan rata-rata 376 gram pada kelompok eksperimen, dan 120 gram pada kelompok kontrol. Dapat disimpulkan bahwa bayi yang dilakukan pemijatan mengalami perubahan berat badan.

Hasil uji $\mathrm{t}$ diperoleh nilai $\mathrm{P}$ value $=0,000$ yang berarti $\mathrm{P}$ value $<a$ maka dapat disimpulkan dalam penelitian ini pijat bayi efektif dalam peningkatan perubahan berat badan.

Penelitian ini hampir senada dengan penelitian yang dilakukan oleh Jin Jing, et al (2012) yang menyatakan pemberian pijatan dan latihan gerak dapat meningkatkan perkembangan fisik dan kecerdasan bayi mulai dari bayi lahir hingga dengan bayi usia 6 bulan dengan $\mathrm{p}=0,010$ untuk indeks berat badan.

Hasil dari penelitian lainnya terkait dengan efektifitas pijat bayi terhadap berat badan pada bayi usia 6 bulan ini senada dengan penelitian yang dilakukan oleh Merineherta (2012) yang menyatakan bahwa ada pengaruh pijat bayi terhadap peningkatan berat badan bayi usia 3-6 bulan, yaitu terdapat perbedaan yang signifikan pada bayi yang dilakukan pemijatan jauh lebih baik dari bayi yang tidak dilakukan pemijatan dengan nilai $\mathrm{p}<0,05$.

Penelitian yang dilakukan Yuliana, Suharto, dan Handayani (2013) kepada bayi usia 3-5 bulan didapatkan peningkatan berat badan bayi dipijat selama 4 minggu yang dilakukan secara rutin lebih tinggi dibandingkan berat badan bayi yang tidak dipijat. Hal ini terjadi karena hormon stress pada bayi menurun, maka bayi dapat menghisap ASI lebih banyak, sehingga produksi ASI meningkat dan berat badan akan meningkat.

Dalam pemaparan Health and Bainbridge Nicki (2012) bahwa pemijatan pada bayi mempunyai banyak manfaatnya antara lain membuat bayi semakin tenang, meningkatkan efektivitas istirahat (tidur) bayi atau balita, memperbaiki konsentrasi bayi, meningkatkan produksi ASI bagi ibu karna bayi sering menyusu, membantu meringankan ketidaknyamanan 
dalam percernaan dan tekanan emosi, memacu perkembangan otak dan sistem saraf, meningkatkan gerak peristaltik untuk pencernaan, memperkuat daya tahan tubuh, meningkatkan kepercayaan ibu dan mempermudah ibu untuk mengenali bayinya, sehingga pada umumnya pijat bayi sangat efektif untuk meningkatkan berat badan, meningkatkan pertumbuhan dan dapat membina kasih sayang orangtua dan anak.

\section{KESIMPULAN}

Berdasarkan penelitian mengenai efektivitas pijat bayi terhadap perubahan berat badan bayi 3-6 bulan di Posyandu Deho di wilayah kerja Puskesmas Hamadi Jayapura tahun 2019.Hasil simpulan yang didapat pada penelitian ini adalah:

1. Pijat bayi efektif terhadap perubahan berat badan rata-rata 376 gram pada bayi usia 3-6 bulan di Posyandu Deho Tahun 2019.

2. Berdasarkan hasil analisis univariat, perubahan berat badan bayi usia 3-6 bulan pada kelompok Eksperimen (yang dilakukan pijat bayi) secara keseluruhan 15 bayi (100\%).

3. Diketahui ada perbedaan rata rata kenaikan berat badan sebelum dan sesudah dilakukan pijat bayi pada kelompok eksperimen dan kelompok kontrol. Hasil uji $\mathrm{t}$ diperoleh nilai $\mathrm{P}$ value $=0,000$ yang berarti $\mathrm{P}$ value $<a$ maka dapat disimpulkan dalam penelitian ini pijat bayi efektif dalam peningkatan perubahan berat badan bayi usia 3-6 bulan di Posyandu Deho di wilayah kerja Puskesmas Hamadi Jayapura tahun 2019.

\section{SARAN}

\section{Bagi Puskesmas}

Adanya petugas kesehatan khususnya di puskesmas untuk dapat melakukan dan memahami tujuan dari pijat bayi ini, sehingga dapat membantu dalam meningkatkan pertumbuhan bayi dan menciptakan masyarakat yang sehat dan sejahtera serta diharapkan untuk puskesmas untuk menambahkan program pijat bayi.

\section{Bagi Masyarakat}

Adanya pemahaman orang tua terhadap stimulasi-stimulasi yang dapat mendukung pertumbuhan bayinya, salah satunya dengan memberikan pijat bayi ini.

\section{Bagi Profesi}

Diharapkan bagi profesi khusunya kebidanan agar lebih menggali lebih mendalam tentang efek-efek fisiologis yang dihasilkan dari pemberian pijat bayi ini.

\section{Bagi peneliti selanjutnya}

Peneliti selanjutnya diharapkan dapat meneliti dengan sampel lebih banyak, menambahkan variabel yang berhubungan dengan pijat bayi tersebut dan menambahkan kelompok umur.

\section{DAFTAR PUSTAKA}

American Association of Message Therapy(AMTA). 2013. Baby Massage. https://www.amtamassage.org/infocenter/healthcare_articles-andassociations.html .Diakses 19 Desember 2018.

Chamidah, A.N. 2013.Deteksi Dini Gangguan Pertumbuhan dan PerkembanganAnak. Jurnal PendidikanKhusus. 
Depkes R.I. 2012. Standar Pelayanan Kebidanan. Departemen Kesehatan Republik Indonesia. Jakarta.

Dewi,Viviannanny liadanTrisunarsih.2010.AsuhanKehamilanuntuk kebidanan.Salemba medika. Jakarta.

Field, T., Schanberg, S., Scafidi.F., Bauer, C., Vega-Lahr, N., Garcia, R., Nystrom, J., Kuhn, C. 1986.Tactile/kinesthetic stimulation effects on preterm neonates.Pediatrics.

Hady, A. 2016.Pengaruh pemijatanpada bayi terhadap peningkatan berat badan di wilayahkerjaPuskesmasWeoe KecamatanWewikuKabupaten Belu. Skripsi.Stikes Nani HusadaParepare.

Gichara.2014. Manfaat Pijat untuk Ibu Hamil, Pasca Melahirkan dan Bayi.Papas Sinar Sinanti. Jakarta.

Jing,Jin.2012.MassageandMotionTrainingForGrowthandDevelopment WorldJPediatr. Guangzhou.

Marineherta.2012. Pengaruh Pijat Bayi TerhadapPeningkatanBeratBadan Bayi Usi 3-6 Bulan di Kelurahan PasiaNan Tigo Kecamatan Koto Tangah KotaPadang.Skripsi.Universitas Andalas.

Ranget,PY. danMegha,Sheth. 2014. Comparative Effectof MassageTherapy versusKangorooMother CareonBody WeightandLengthofHospital StayinLowBirth Weight PreternInfants. Journal of Neonatal Intensive Care Unit.College of Physiotheraphy India.

Riskesdas. 2011. Badan Penelitian Pengembangan Kesehatan Kementerian Kesehatan RI 2011. Riset Kesehatan Daerah. Riskesdas: 2011. Jakarta.

Roesli,Utami.2013.PedomanPijatBayiBayi.PustakaPembangunan Swadaya Nusantara. Jakarta.

Sari, P. 2012. Efektifitas pijat bayi terhadap pertumbuhan dan perkembangan bayi usia 6 bulan di Kelurahan Bintaro Jakarta. Skripsi.Universitas Islam Negeri Syarif Hidayatullah Jakarta.

Soedjatmiko.2013. PentingnyaStimulasi Dini Untuk MerangsangPerkembangan Bayi dan BalitaTerutamaPadaBayi Resiko Tinggi. Sari Pediatri. Jakarta.

Subakti dan Anggarani.2014. Keajaiban Pijat Bayi dan Balita. Jakarta.

Sulung,N.,Gayatri,A.2015.EfektivitasMassageBaby TerhadapPeningkatanBerat BadanBayiUsia 3-4Bulan DiBPSBUNDAKecamatanMandianginKoto Selayan Bukittinggi Tahun 2015.Skripsi.Universitas Muhammadiyah Purwokerto.

Supariasa.2012. Penilaian Status Gizi.EGC. Jakarta.

Tanuwijaya, S. 2013. Konsep Umum Tumbuh dan Kembang.EGC. Jakarta.

Widyastuti,RrDanisdanRetnoWidyani.2013.PanduanPerkembanganBayi0-1 Tahun. Niaga Swadaya. Jakarta

Sunarsih, Tri. 2010. Pengaruh Pijat Bayi Terhadap Kenaikan Berat Badan Bayi Umur 0-3 bulan di BPS Saraswati Sleman Yogyakarta.Skripsi.Universitas Aisyiyah Yogyakarta.

Yuliana, A. \& Suharto, A. \& Handayani, T. (2013). Perbedaan berat badan bayi usia 3-5 bulan yang dipijat dan tidak dipijat (di Kelurahan Tawanganom Kecamatan Magetan tahun 2013). Jurnal Penelitian Kesehatan Suara Forikes. Stikes Budi Luhur Cimahi.

Widyani.2013.PanduangPerkembanganAnak0sampailtahun.Puspa Swara. Jakarta.

WHO. 2013.Beyond The Numbers: Reviewing MaternalDeaths and ComplicationstoMake PregnancySafer.Geneva. WHO 